\title{
Physiological Aspects of Cauliflower Plants Affected by Fertigation Intervals and Doses of Various Inter - Season Soil Ameliorants in Coastal Sandy Land
}

\author{
DOI: 10.18196/pt.2018.084.84-91
}

\author{
Mahbub Junaedi*, Saparso, Muhammad Rif'an \\ Postgraduate of Agronomic Study, Faculty of Agriculture, Universitas Jenderal Soedirman, \\ Jl. Dr. Soeparno No 61, Purwokerto 53123 Jawa Tengah, Indonesia, Telp/Fax: (0281) 638791 \\ *Corresponding author, email: mahbubcilacapkab@yahoo.com
}

\begin{abstract}
Cauliflower is one of vegetable commodities mostly consumed. The study aimed to determine fertigation interval and application of soil ameliorants including the types, doses, and frequency that are appropriate for the growth and productivity of cauliflower plants in coastal sandy land. The research was carried out in the sandy beach area of Jetis, Banjarsari Village, Nusawungu District, Cilacap Regency from April 2017 to September 2017. The study was arranged in Randomized Complete Block Design (RCBD) factorial split plot. Data were analyzed by ANOVA followed by DMRT at $5 \%$. The results showed that (1) the fertigation interval did not significantly affect the growth, yield and physiology variables of cauliflower plants; (2) the frequency of soil ameliorants application had significant effect on the variable growth and yield of cauliflower plants. The application of soil ameliorants every season gave the best results compared to application every two seasons; (3) the application of soil ameliorants of Vertisol soil and manure could increase growth and yield variables compared but did not affect the physiology of cauliflower plants.
\end{abstract}

Keywords: Cauliflower, Fertigation interval, Soil type, Doses

\section{ABSTRAK}

Kubis bunga merupakan salah satu komoditas sayuran yang banyak di konsumsi. Penelitian bertujuan untuk Menentukan interval fertigasi, frekuensi pemberian pembenah tanah, jenis dan dosis pembenah tanah yang tepat untuk pertumbuhan dan produktivitas tanaman kubis bunga di lahan pasir pantai. Penelitian dilaksanakan di lahan pasir pantai Jetis, Desa Banjarsari, Kecamatan Nusawungu, Kabupaten Cilacap. Penelitian dilaksanakan Bulan April 2017 sampai dengan September 2017. Penelitian menggunakan Rancangan Acak Kelompok Lengkap (RAKL) faktorial split plot. Data dianalisis dengan uji F dilanjutkan dengan DMRT 5 \%. Hasil penelitian menunjukkan bahwa (1) Interval pemberian fertigasi tidak berpengaruh nyata terhadap variabel pertumbuhan, hasil dan fisiologi tanaman kubis bunga. (2) Frekuensi pemberian pembenah tanah berpengaruh nyata terhadap variabel pertumbuhan dan hasil kubis bunga. Frekuensi pemberian pembenah tanah tiap musim memberikan hasil yang terbaik dibandingkan pemberian 2 musim sekali. (3) Pemberian pembenah tanah vertisol dan pupuk kandang dapat meningkatkan variabel pertumbuhan dan hasil dibandingkan yang tidak menggunakan pembenah tetapi tidak berpengaruh terhadap fisiologi tanaman kubis bunga.

Kata Kunci: Kubis bunga, Interval fertigasi, Jenis pembenah tanah, Dosis

\section{INTRODUCTION}

Cauliflower is vegetable plant with high nutritional value containing several substances needed by human body including vitamins and minerals that are beneficial for the digestive system and neutralizing acidic substances (Pracaya, 2001). According to data from the Ministry of Agriculture of the Directorate General of Horticulture (2015), national production of cabbage in 2014 amounted to 136,508 tons planted on a land area of 11,303 hectares with a productivity rate of 12.08 tons / hectare.

Coastal areas can be alternatives for agricultural cultivation with all the consequences to overcome the limitations by using technological input (Sunarto G, 2002). Sandy soil of coastal areas has low CEC $\left(5.640 \mathrm{cmol}^{(+)} \mathrm{kg}^{1}\right)$, low $\mathrm{N}$-available $\mathrm{N}$ (26.786 ppm), low C-organic (0.389\%), as well as low $\mathrm{K}, \mathrm{Na}$, and $\mathrm{Ca}$. This land has field capacity and permanent wilt point of 10.186 and $1.922 \%$, respectively, with a specific gravity of $1.46 \mathrm{~g} / \mathrm{cm}^{3}$ (Saparso, 2008).

The addition of soil ameliorants is one way to improve soil conditions. Soil ameliorants can improve soil structure, so that water will be retained longer in the soil (Sutono et al., 1997). Soil ameliorants that can be used in coastal sandy land include 
Table 1. The Analysis Results of The Growth, Yield Variables, and Physiological Traits of Cauliflower as Affected by the Type of Soil Ameliorants

\begin{tabular}{lccc}
\hline \multirow{2}{*}{ Variable } & \multicolumn{3}{c}{ Treatment } \\
\cline { 2 - 4 } & $\mathrm{I}$ & $\mathrm{M}$ & $\mathrm{JD}$ \\
\hline Growth variables & & & \\
Plant height (cm/plant) & $\mathrm{ns}$ & $\mathrm{ns}$ & $\mathrm{SS}$ \\
Number of leaves & $\mathrm{ns}$ & $\mathrm{ns}$ & $\mathrm{ns}$ \\
Leaf weight (cm/plant) & $\mathrm{ns}$ & $\mathrm{S}$ & $\mathrm{SS}$ \\
Leaf area (cm²/plant) & $\mathrm{ns}$ & $\mathrm{ns}$ & $\mathrm{ns}$ \\
Root length (cm/plant) & $\mathrm{ns}$ & $\mathrm{S}$ & $\mathrm{SS}$ \\
Root volume (ml/plant) & $\mathrm{ns}$ & $\mathrm{ns}$ & $\mathrm{S}$ \\
Roots fresh weight (g/plant) & $\mathrm{ns}$ & $\mathrm{S}$ & $\mathrm{S}$ \\
Roots dry weight (g/plant) & $\mathrm{ns}$ & $\mathrm{ns}$ & $\mathrm{ns}$ \\
Leaves fresh weight (g/plant) & $\mathrm{ns}$ & $\mathrm{S}$ & $\mathrm{SS}$ \\
Leaves dry weight (g/plant) & $\mathrm{ns}$ & $\mathrm{S}$ & $\mathrm{ns}$ \\
Plant fresh weight (g/plant) & $\mathrm{ns}$ & $\mathrm{S}$ & $\mathrm{SS}$ \\
Plant dry weight (g/plant) & $\mathrm{ns}$ & $\mathrm{S}$ & $\mathrm{SS}$ \\
Stem fresh weight (g/plant) & $\mathrm{ns}$ & $\mathrm{SS}$ & $\mathrm{SS}$ \\
Stem dry weight (g/plant) & $\mathrm{ns}$ & $\mathrm{ns}$ & $\mathrm{SS}$ \\
Yield variables & & & \\
Head fresh weight (t/ha) & & $\mathrm{n}$ & $\mathrm{SS}$ \\
Head dry weight (g/plant) & $\mathrm{ns}$ & $\mathrm{S}$ & $\mathrm{SS}$ \\
Diameter of head (cm/plant) & $\mathrm{ns}$ & $\mathrm{ns}$ & $\mathrm{ns}$ \\
Physiological traits & & & \\
Chlorophyll a (mg/l) & $\mathrm{ns}$ & $\mathrm{ns}$ \\
Chlorophyll b (mg/l) & $\mathrm{ns}$ & $\mathrm{ns}$ \\
\hline
\end{tabular}

Note: $\mathrm{ns}=$ not significantly different based on ANOVA at $5 \%, \mathrm{~S}=$ significantly different based on ANOVA at $5 \%, S S=$ significantly different based on ANOVA at $1 \%$. I = fertigation interval, $M=$ frequency of soil ameliorants application, JD = combination of soil ameliorants type and dose.

Vertisol soil and manure. According to Prasetyo (2007), the composition of clay minerals in Vertisol is not only smectite, but also kaolinite, illite and vermiculite. Manure has high CEC which is $30.99 \mathrm{me} / 10 \mathrm{~g}$ and high $\mathrm{N}$-available which is 290 ppm (Saparso, 2008). High efficiency in fertilizing, besides increasing crop yields, also saves fertilizer use and reduces the risk of environmental pollution. Fertilization efficiency is strongly influenced by leaf distribution patterns and the ability of plants to utilize nutrients and water from the soil (Turmudi, 1999).
This research is expected to be able to complete the site-specific technology to improve the efficiency of land resource utilization, especially manure, and to decrease the cost of nitrogen fertilization on coastal sandy land. Efforts to increase vegetable production in the future will continue to rely on the use of external inputs, including manure and chemical fertilizers, which are needed to meet the plant nutrient needs. On that basis, the dose of nutrient requirements for plants is necessary to be considered in its management, so that it can be developed sustainably.

\section{MATERIALS AND METHODS}

The research was conducted from April 2017 to September 2017 in the sandy beach area of Jetis, Banjarsari Village, Nusawungu District, Cilacap Regency. The materials used included TM126F1 cauliflower seeds produced by PT. Panah Merah, vertisol, Urea, ZA, SP-36, KCl, cow manure, and chicken manure. The tools used were paralon pipes and water reservoirs, drip irrigation emitters, hoses, pumps, digital scales, ovens, hoes, pans, buckets, sprayers, rollers, saws, scissors and rulers.

The research was arranged in Randomized Complete Block Design (RCBD) factorial split plot with 3 replications. The first factor was fertigation interval (I) consisting of 2 levels, i.e. 7 days (I1) and 14 days (I2). The second factor was the frequency of soil ameliorants application (M) consisting of 2 levels, i.e. every season (M1) and once in two seasons (M2). The third factor was the type of soil ameliorants (J) consisting of 3 levels, i.e. vertisol (30 t/ha) (J1), mixture of chicken manure: cow manure $=1: 1(20 \mathrm{t} / \mathrm{ha})(\mathrm{J} 2)$, vertisol and mixture of chicken manure: cow manure $=1: 1(30 \mathrm{t} / \mathrm{ha}$; $20 \mathrm{t} / \mathrm{ha}$ ) (J3). And the fourth factor was doses of soil ameliorants application (D) consisting of 3 levels, i.e. 100\% (D1), 200\% (D2) and 300\% (D3). Variables observed included plant height, num- 


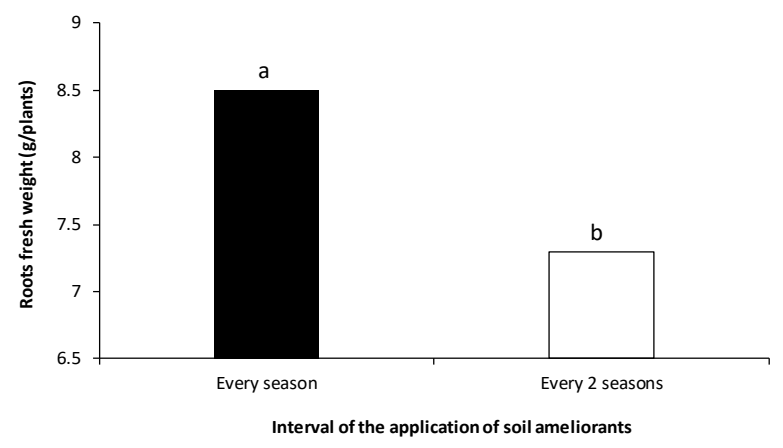

Figure 1. Root Fresh Weight of Cauliflower with Different Interval of Soil Ameliorans Application

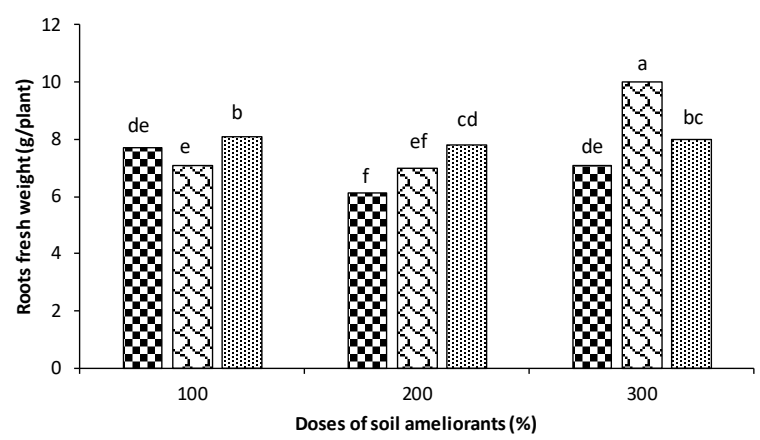

Type of soil ameliorants:

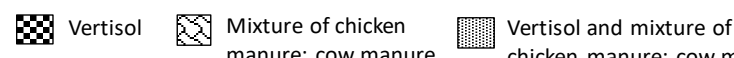
manure: cow manure chicken manure: cow manure

Figure 2. Root Fresh Weight of Cauliflower with Different Doses and Type of Soil Ameliorants

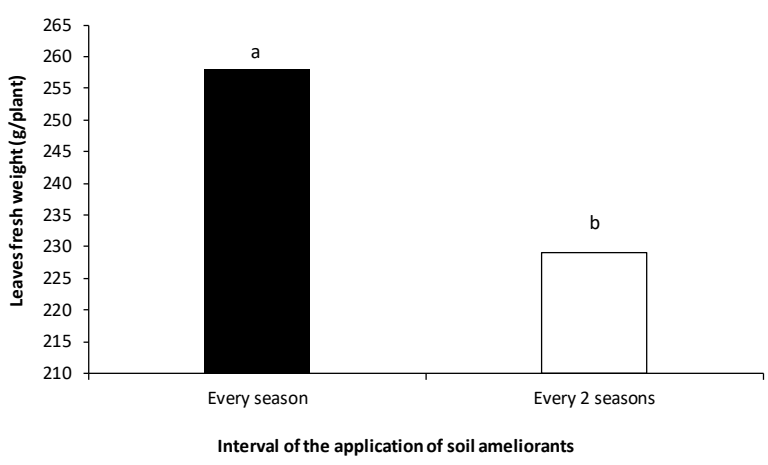

Figure 3. Leaves Fresh Weight of Cauliflower with Different Interval of Soil Ameliorans Application

ber of leaves, leaf length, leaf area, roots length, roots volume, roots fresh weight, roots dry weight, leaves fresh weight, leaves dry weight, plant fresh weight, plant dry weight, stem fresh weight, stem dry weight, head fresh weight, head dry weight, diameter of head, chlorophyll a and chlorophyll b.
Data were analysed using DSAASTAT software. Data collected were analysed with Analysis of Varians (ANOVA) at 5\%. Significant differences among treatments were tested using DMRT at 5\%.

\section{RESULTS AND DISCUSSION}

Effects of the treatments on the growth, yield and physiological traits of cauliflower plants based in ANOVA results are presented in Table 1.

\section{Roots fresh weight (g/plant)}

The application of soil ameliorants every season gave the best results for the variable of roots fresh weight reaching $8.51 \mathrm{~g} /$ plant. This value is significantly higher than that of plants treated with soil ameliorants application once every 2 seasons which is $7.3 \mathrm{~g} /$ plant (Figure 1). Some research results showed that the application of manure always gave the best plant response. Nengah (2017) mentioned that the provision of chicken manure at a dose of 10 tons/ha had significant effect on the roots fresh weight.

The combination of soil ameliorants type and doses significantly affected the roots fresh weight. The application of a mixture of chicken and cow manure at a dose of $300 \%$ resulted in the highest roots fresh weight (10.35 g/plant), while the application of $200 \%$ vertisol gave the lowest results which was $6.57 \mathrm{~g} /$ plant (Figure 2).

The application of chicken manure influences plant growth. This occurs because chicken manure is relatively more decomposed and it has enough nutrient content compared to other manure types in the same number of units (Widowati et al., 2005).

\section{Leaves fresh weight (g/plant)}

The interval of soil ameliorants application affected the variable of leaves fresh weight. The 


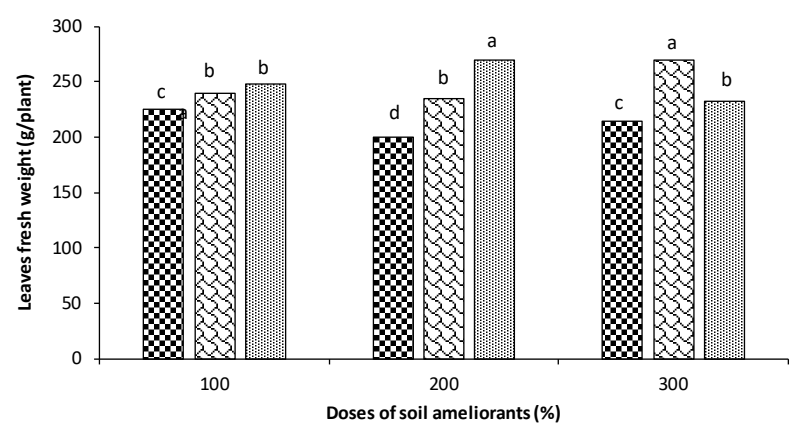

Type of soil ameliorants:

3 vertisol
Mixture of chicken
manure: cow manure

Figure 4. Leaves Fresh Weight of Cauliflower with Different Doses and Type of Soil Ameliorants

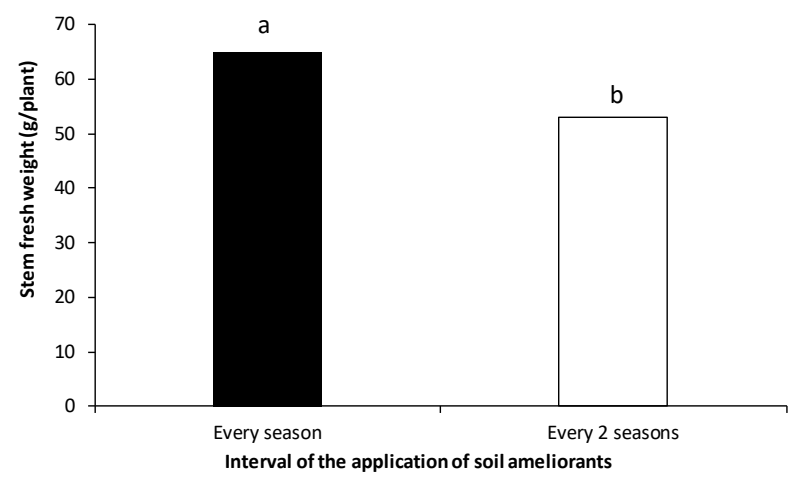

Figure 5. Stem Fresh Weight of Cauliflower with Different Interval of Soil Ameliorans Application

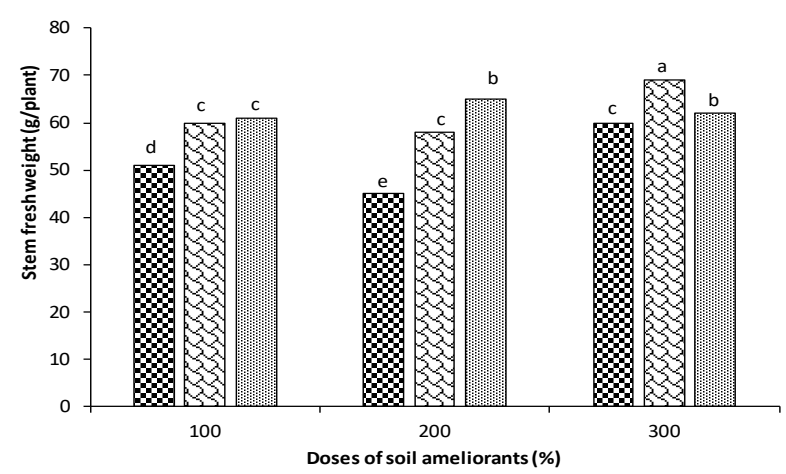

Type of soil ameliorants:

3 Vertisol $\begin{aligned} & \text { Mixture of chicken } \\ & \text { manure: cow manure }\end{aligned}$
chicken manure: cow manure

Figure 6. Stem Fresh Weight of Cauliflower with Different Doses and Type of Soil Ameliorants

application of soil ameliorants every season gave the best results on the variables of leaves fresh weight, which was equal to $257.87 \mathrm{~g} /$ plant. This value is significantly higher than that of plants treated with soil ameliorants application once every 2 seasons, which was $228 \mathrm{~g} /$ plant. (Figure 3) The highest value of leaves fresh weights resulted from the application of soil ameliorant every planting season is in accordance with Kartasapoetra (1988) mentioning that nutrient losses in the soil occur due to leaching and erosion of water which can eliminate $\mathrm{N}$ and $\mathrm{P}$ elements but not as much as loss $\mathrm{Ca}$ and $\mathrm{Mg}$ available. Thus, nutrients need to be given as a substitute for nutrients that have been lost by supplying soil ameliorants every planting season, especially in cauliflower.

The combination of types and doses of soil ameliorants had significant effects on the fresh weight of leaves. The application of $300 \%$ mixture of chicken and cow manure produced the highest leaves fresh weight, i.e. $273.56 \mathrm{~g} /$ plant in whiche the value is not significantly different from that of plants treated with $200 \%$ of vertisol mixed with chicken and cow manure which was 272.27 g / plant. Meanwhile, the application of 2s00\% vertisol resulted in the lowest leaves fresh weight amounted to $205.68 \mathrm{~g} /$ plant (Figure 4).

This is because organic matters decomposed from soil ameliorants given in the first planting season can increase the water holding capacity. The combination of types and doses of soil ameliorants had a very significant effect on the fresh weight of leaves. According to Widarma (2016), the application of cow manure at a dose of 30 tons / ha on caulififlower plants gave a significant effect on the number of leaves, weight of head along with the leaves, head weight of head without leaves, dimeter of head and yield per hectare.

\section{Stem fresh weight (g/plant)}

The interval of soil ameliorants application significantly affected the stem fresh weight. The application of soil ameliorants every season resulted in the highest stem fresh weight reaching $66.19 \mathrm{~g}$ 


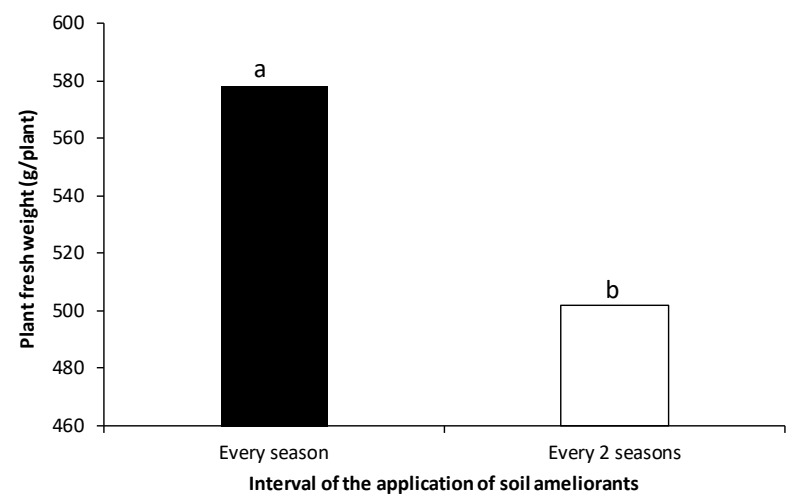

Figure 7. Plant Fresh Weight of Cauliflower with Different Interval of Soil Ameliorans Application

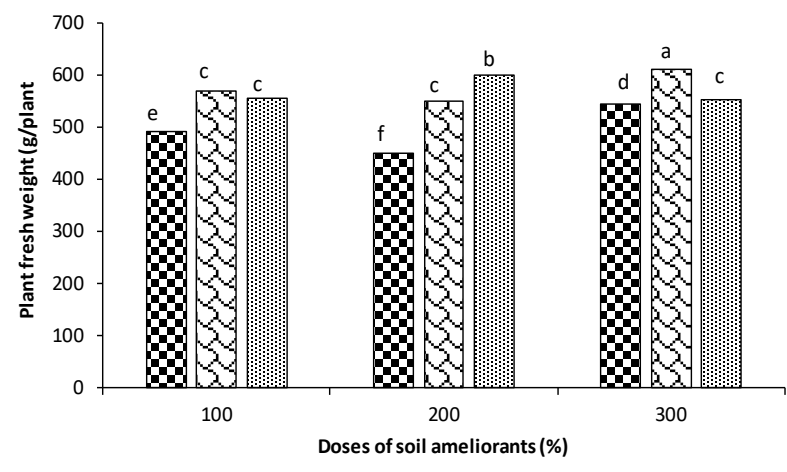

Type of soil ameliorants:

Vertisol
$\begin{aligned} & \text { Mixture of chicken } \\ & \text { manure: cow manure }\end{aligned}$

Figure 8. Plant Fresh Weight of Cauliflower with Different Doses and Type of Soil Ameliorants

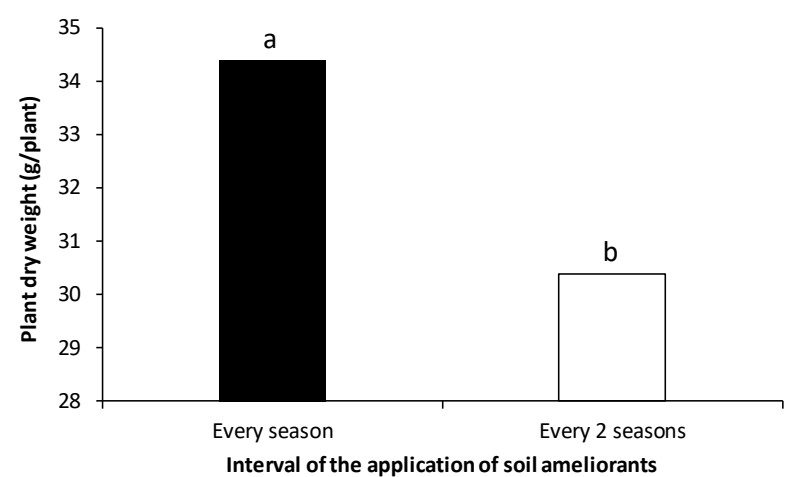

Figure 9. Plant Dry Weight of Cauliflower with Different Interval of Soil Ameliorans Application

/ plant. This value was significantly higher than that of plants treated with soil ameliorants once every 2 seasons showing value of $54.59 \mathrm{~g} /$ plant (Figure 5). According to Lingga (1998), the main role of nitrogen is to stimulate plant growth, one of which is stem. Thus, to supply enough nutrient, the addition of cow and chicken manure is suggested.

The combination of soil ameliorants type and doses had significant effects on the stem fresh weight. The application of chicken and cow manure mixture with a dose of $300 \%$ gave the best results for stem fresh weight amounted to $70.62 \mathrm{~g} /$ plant. Meanwhile, the application of $200 \%$ vertisol resulted in the lowest stem fresh weight which was $46.87 \mathrm{~g} /$ plant (Figure 6).

The application of soil ameliorants is one way to improve soil conditions. Soil ameliorants can improve soil structure, so that water will be retained longer in the soil (Sutono et al., 1997). Some of the advantages of using manure are improving soil structure and texture and increasing water uptake ability of the soil (Wiryanta, 2003).

\section{Plant fresh weight (g/plant)}

The interval of soil ameliorants application affected the fresh weight of plant. The application of soil ameliorants every season resulted in the highest value of plant fresh weight which was $575.91 \mathrm{~g} /$ plant. This value is significantly higher than that of plants treated with soil ameliorants once every 2 seasons showing value of $505.79 \mathrm{~g} /$ plant (Figure 7).

According to Saragih (2013), nutrients available in enough quantities during vegetative growth will enhance active photosynthesis thus more protein will be formed. The results of photosynthesis are used for the growth of plant organs, in which the larger plant organs are formed, the more water content can be bound by plants.

The combination of types and doses of soil ameliorants significantly affected plant fresh weight. The application of $300 \%$ mixture of chicken and cow manure resulted in the highest value of plant fresh weight ameounted to $613.32 \mathrm{~g} /$ plant. Meanwhile, the application of $200 \%$ vertisol pro- 


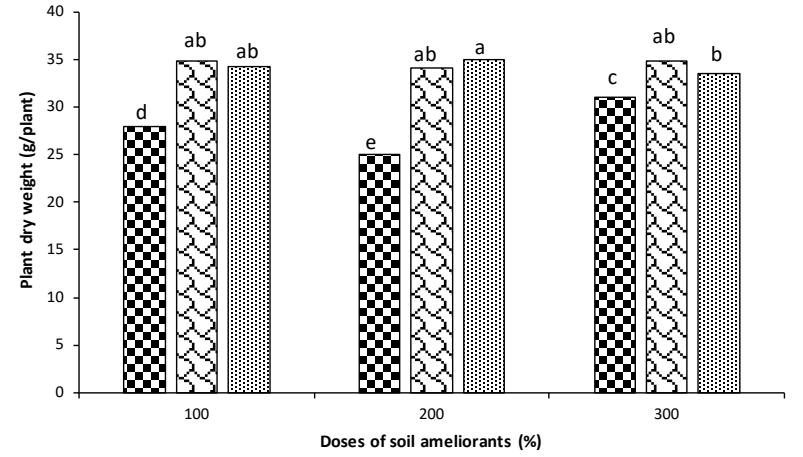

Type of soil ameliorants:

8 vertisol
mixture of chicken
manure: cow manure $\begin{aligned} & \text { Vertisol and mixture of } \\ & \text { chicken manure: cow manure }\end{aligned}$

Figure 10. Plant Dry Weight of Cauliflower with Different Doses and Type of Soil Ameliorants

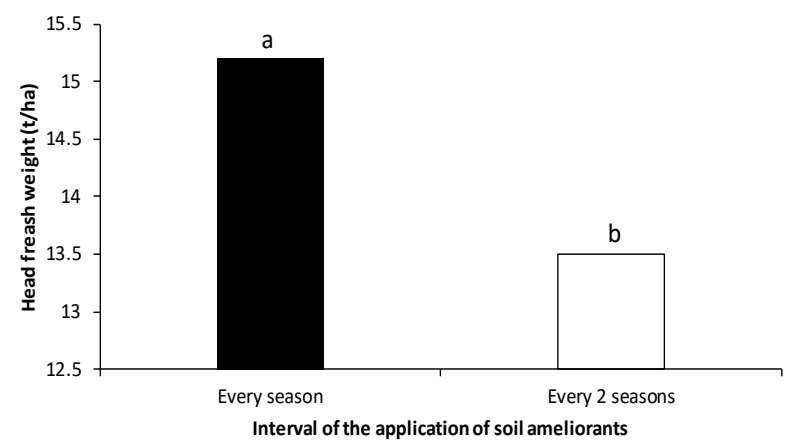

Figure 11. Head Fresh Weight of Cauliflower with Different Interval of Soil Ameliorans Application

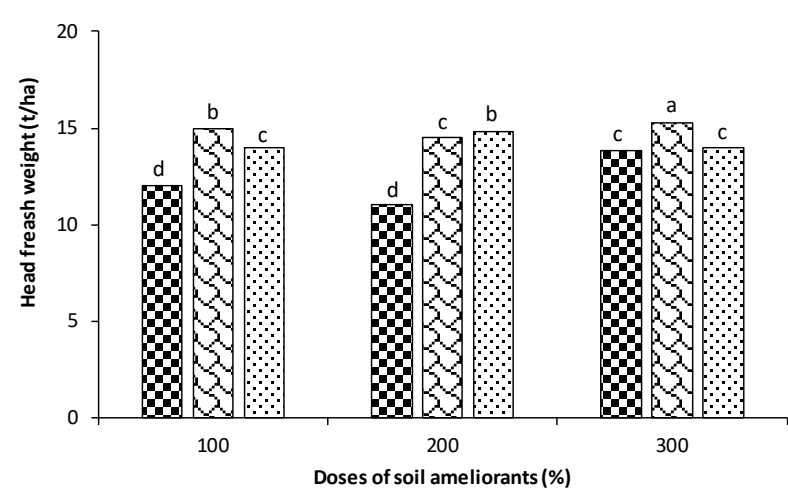

Type of soil ameliorants:

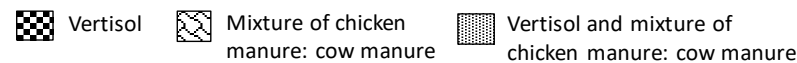
Head Weight of Cauliflower with Different Doses and Type of Soil Ameliorants
2016). The fresh weight of cauliflower plants without provision of soil ameliorants is lower than that of plants treated with soil ameliorants. Welfi's research (2014) showed that application of bokashi manure at a dose of 15 tons / ha was able to increase the fresh weight of caisim plant.

\section{Plant dry weight (g/plant)}

The interval of soil ameliorants application significantly affected the dry weight of plants. The application of soil ameliorants every season gave the best results for plant dry weight which was 34.5 $\mathrm{g} / \mathrm{plant}$. This value was significantly higher than that of plants treated with soil ameliorants once every 2 seasons reaching a value of $30.44 \mathrm{~g} /$ plant (Figure 9).

According to Sarief (1989), the initial growth of plants will require a large amount of nutrients. The application of soil ameliorants every planting season can provide relatively large amounts of nutrients from available organic matter compared to soil ameliorants application every 2 planting seasons.

The combination of soil ameliorants types and doses had significant effects on the plant dry weight. The application of $200 \%$ vertisol mixed with chicken and cow manure produced the highest plant dry weight of $34.98 \mathrm{~g} /$ plant. Meanwhile, the application of $200 \%$ vertisol resulted in lowest value which was $25.88 \mathrm{~g} /$ plant (Figure 10).

According to the research by Puspita sari et al. (2016), the application of chicken manure with doses of 5 tons/ha and 10 tons/ha gave significantly different effects from doses of 15 tons/ha and 20 tons/ha on the plant dry weight of pakchoy plants (Brassica rapa L. var. Chinensis). According to Indrasaril and Abdul (2006), the provision of duced the lowest result which was $440.46 \mathrm{~g} /$ plant nutrients both macro and micro in enough and (Figure 8).

balanced amounts can increase the nutrients

Soil ameliorants in the form of manure increases needed by plants and they can be used as energy the fresh weight of plants by $36.5 \%$ (Mulatsih, source for plants. 


\section{Head freash weight (t/ha)}

The interval of soil ameliorants application significantly affected head fresh weight of cauliflower plants. The application of soil ameliorants every season resulted in the highest head fresh weight which was 15.21 ton/ha. This value is significantly higher than that of plants treated with soil ameliorants once every 2 seasons, i.e. $13.49 \mathrm{t} /$ ha (Figure 11).

According to Goldsworthy and Fisher (2002), the supply of nutrients including nitrogen has a major influence on flowering and subsequently affects the yield. Flower becomes the dominant organ for carbohydrate storage and there will be a decline in growth.

The combination of $300 \%$ mixture of chicken and cow manure produced the highest head fresh weight which was $16.17 \mathrm{t} / \mathrm{ha}$. Meanwhile, the application of $200 \%$ vertisol resulted in the lowest result, i.e.11.33 t/ha (Figure 12).

Intara (2011) mentioned that provisioning organic matter can increase the availability of water content. The addition of good organic matter in the form of chicken manure and compost can increase water content available in the soil compared to without organic matter addition. According to Sitompul and Guritno (1995), the head fresh weight is indicator of a good plant. The water content in the head (flower) is thought to affect the yield of fresh head. The more water content in the head (flower), the weight of the head (flower) will be increased.

\section{CONCLUSIONS}

1. Fertigation interval had no significant effects on the growth, yield, and physiological traits of cauliflower plants.

2. Frequency of the application of soil ameliorants significantly affected the growth and yield of cauliflower plants. The application of soil ameliorants every planting season gave better results compared to the application once every 2 seasons.

3. The provision of vertisol and manure was able to improve the growth and yield of cauliflower plants. However, it did not have significant effects on the physiological traits of cauliflower plants.

\section{REFERENCES}

Goldsworthy, P.R., and N. M Fisher. 2002. The Physiology of Tropical Field Crops (Fisiologi Tanaman Budidaya Tropik, Terjemahan Tohari). Penerbit Gadjah Mada University Press, Yogyakarta. 874p Indrasaril, A. dan Abdul. 2006. Pengapuran Pemberian Pupuk Kandang dan Unsur Hara Mikro Terhadap Pertumbuhan Jagung pada Ultisol yang Dikapur. Jurnal ilmu tanah dan lingkungan 6 (2): 116-123

Intara, I.Y. 2011. Pengaruh Pemberian Bahan Organik Pada Tanah Liat dan Lempung Berliat Terhadap Kemampuan Mengikat Air. Jurnal IImu Pertanian Indonesia. 16(2): 130-135

Kementerian Pertanian Direktorat Jenderal Hortikultura. 2015. Statistik Produksi Hortikultura Tahun 2015. http://hortikultura.pertanian.go.id/wp-content/uploads/2016/02/StatistikProduksi-2014.pdf. Acces on February 2016

Mulatsih Anisah Tri. 2016. Pengaruh Pertumbuhan Dan Hasil Tanaman Kubis Bunga Pada Berbagai Pembenah TanahDan Takaran Pupuk Nitrogen di Lahan Pasir Pantai. [Skripsi]. Universitas Jenderal Soedirman. Purwokerto

Nengah, S.l., 2017. Pengaruh Jenis Pupuk Organik terhadap Pertumbuhan Tanaman Bayam (Amaranthus sp.) pada Tanah Tegalan Asal Daerah Kubu, Karangasem, Program Study of Agroteknologi, Faculty of Agriculture, Universitas Mahasaraswati Denpasar

Pracaya. 2001. Kol alias Kubis. Penebar Swadaya, Jakarta. 39-43p

Prasetyo, B.H. 2007. Perbedaan Sifat-Sifat Tanah Vertisol dari Berbagai Bahan Induk. Jurnal IImu-IImu Pertanian Indonesia 9 (1): 20 - 31

Saparso. 2008. Ekofisiologi Tanaman Kubis Bawah Naungan dan Pemberian Bahan Pembenah Tanah di Lahan Pasir Pantai. Disertasi - S3 Pasca Sarjana UGM, Yogyakarta. 277p

Saragih, D., H. Hamim and N. Nurmauli. 2013. Pengaruh Dosis dan Waktu Aplikasi Pupuk Urea dalam Meningkatkan Pertumbuhan dan Hasil Jagung (Zea mays L.) Pioneer 27. J. Agrotek Tropika 1(1): 50-54

Sari R.M.P., M.D Maghfoer., Koesriharti. 2016. Pengaruh Frekuensi Penyiraman Dan Dosis Pupuk Kandang Ayam Terhadap Pertumbuhan Dan Hasil Tanaman Pakchoy (Brassica rapa. L. var. chinensis. Jurnal Produksi Produksi Tanaman 4 (5): 342-351

Sarief, S. 1989. Kesuburan dan Pemupukan Tanah Pertanian. Pustaka Buana. Bandung.

Sitompul, S.M. and B. Guritno. 1995. Analisis Pertumbuhan Tanaman. Gadjah Mada University Press. Yogyakarta 
Sunarto, G. 2002. Teknologi Pemanfaatan Lahan Marginal Kawasan Pesisir. Jurnal Teknologi Lingkungan 3 (3): 232-236

Sutono and Abdurachman. 1997. Pemanfaatan soil conditioner dalam upaya rehabilitasi lahan terdegradasi. Prosiding Pertemuan Pembahasan dan Komunikasi Hasil Penelitian Tanah dan Agroklimat, Pusat Penelitian Tanah dan Agroklimat 107-122

Turmudi E. 1999. Efektivitas Pemupukan Nitrogen dan Inokulasi Bradyrhizonium japonicora pada Sistem Pertanaman Tumpang Sari Kedelai dan Jagung. Fakultas Pertanian. Universitas Bengkulu. Bengkulu

Welfi, F. 2014. Pengaruh Takaran Bokashi Pupuk Kandang Sapi Dan Takaran Gandasil D Terhadap Pertumbuhan Dan Hasil Tanaman Caisim (Brassica juncea L.). [Skripsi]. Universitas Taman Siswa. Padang.

Widowati. L. R., Sri Widati, U. Jaenudin, and W. Hartatik. 2004. Pengaruh kompos pupuk organik yang Dipekaya dengan Bahan Mineral dan Pupuk Hayati terhadap Sifatsifat Tanah, Serapan Hara dan Produksi Sayuran Organik. Laporan Proyek Penelitian Program Pengembangan Agribisnis. Balai Penelitian Tanah.

Widarma, 2016. Respons Kubis Bunga (Brassica Oleracea Var. Botrytis L.) Terhadap Berbagai Jenis Mulsa Plastik Dan Dosis Pupuk Kandang. [Skripsi] STIPER. Lampung.

Wiryanta. W. 2003. Bertanam Cabai Hibrida Secara Intensif. Agromedia Pustaka. Jakarta. $128 \mathrm{p}$ 